\title{
University and Enterprises Linkages for Regional Development in México
}

\section{Moctezuma, Patricia ${ }^{a}$; López, Sergio ${ }^{b}$ and Munagaray, Alejandro ${ }^{c}$}

${ }^{a}$ Autonomous University of Baja California. Dean of Graduate Studies Coordination and Research, Álvaro Obregón sin número, Col. Nueva, Mexicali, B.C. 21100, México; ${ }^{\mathrm{b}}$ Autonomous University of Baja California. School of Administrative Science, Bulevar Río Nuevo, Agualeguas, 21090 Mexicali, B.C. 21330, México; 'Autonomous University of Baja California. School of Economics and International Relations, Calzada Universidad 14418 Parque Industrial Internacional Tijuana, Tijuana B.C. 22390, México.

\begin{abstract}
This article evaluates the incentives to Mexico Innovation Program (PEI), from a regional perspective based on its contribution to the Regional Innovation System (RIS) of Baja California, between 2009 and 2013. Through the both additional behavioral and networks methodologies, the decision making process at companies, and the level of linkages among them, higher education institutions and governmental actors of the RIS is analyzed. The results show that by imposing the financing of innovation projects on the linking of business and scientific actors, PEI is helping to strengthen the RIS, encouraging $15 \%$ of its interactions.
\end{abstract}

Keywords: Regional Innovation System, Evaluation Program Innovation Stimulus, Scientific Policy, Business Innovation, Regional Development in Mexico. 


\section{Introduction}

In 2009, the implementation of the Incentives to Innovation Program (PEI) in Mexico started, fostering the linkages among companies that seek to be more competitive through improvements in their processes and products, with Higher Education Institutions (HEIs), promote learning and major changes within the organizations that interact, as well as impacts on the Regional Innovation Systems (RIS).

In 2009, Calderón (2009) evaluated the first edition of the PEI, with an emphasis on design but without considering the regional aspect. In 2013, the National Council for Evaluation of Social Development Policy (CONEVAL, 2013) evaluated the PEI at national level between 2011 and 2013, with results not fully attributable to the intervention of the PEI.

To evaluate the impacts at the regional level, this paper analyzes the PEI during the years 2009 to 2013, in the Mexican state of Baja California. The objective is to know the impacts on the companies that have participated in the program and how they are reflected in the RIS, through the creation of networks of knowledge between the beneficiary companies and the scientific and technological structure that supports innovation. The centralized structure of PEI resources promotes that each region looks to capture the greatest possible benefits, to strengthen specific aspects of its development (FCCYT, 2006).

With the objective of demonstrating that the PEI contributes to the strengthening of the IRS by encouraging projects that broaden the interactions between the actors, first section review the background of the program and the literature on the characteristics of RIS and the economic advantages of the interaction Network that gives rise to the dynamics of innovation. The second section presents the behavior additionality and social networks methodology as pertinent to study the behavior and interaction of companies and HEIs. Results analysis is done, with emphasis on the interactions and connectivity of the networked system. Finally the conclusions are developed, highlighting how and to what extent the PEI contributes to the system connections. 


\section{Background}

Tax incentives in Mexico are born under an initiative of the Mexican Association of Applied Research and Technological Development (ADIAT), to increase private investment in national research and development ( $\&$ \&) and stimulate its link with HEIs. The program did not generate the expected results and since its inception it has undergone significant sub-exercises and concentration in large, mainly multinational companies, which in 2005 accounted for $60 \%$ of the requested incentives. Its greatest weakness was the laxity with which considered R \& D projects was defined. This allow that in many occasions they supported marginal or developed innovations in other countries (OECD, 2010).

In response to recommendations from the Organization for Economic Cooperation and Development (OECD), the Secretary of Finance and Public Credit (SHCP) decided to cancel the program in 2008 and implement a new one that only supports projects that have a significant impact on $\mathrm{R} \& \mathrm{D}$ in the country; set a ceiling on resources for large enterprises; and conduct a comprehensive annual program evaluation (OECD, 2008). In 2009 the PEI is implemented with complementary economic incentive. The beneficiaries were all Mexican companies registered in the National Register of Scientific and Technological Institutions and Companies (RENIECYT) that carry out activities related to Research, Technological Development and Innovation (IDTI) individually, or in association with HEI and / or Centers and research institutes (CIs).

The IEP is composed of three subprograms: INNOVAPYME complements with public resources the investment in IDTI of micro, small and medium enterprises. INNOVATEC encourages investment in IDTI of large companies. PROINNOVA fosters the flow of knowledge between business actors of both sizes with HEIs and CI. This latest encourages the creation and permanence of innovation networks or strategic alliances for the development of projects in precursor fields of knowledge, that are translated into products, processes or services of high added value, with regional, sectorial and social impact. All modalities allow companies to have new patents, products, processes or services that improve their competitiveness and thereby promote the competitive advantages of each region or entity. 
Table1. Amounts of PEI Support for fiscal year 2013

\begin{tabular}{|c|c|c|c|c|c|}
\hline \multirow{3}{*}{ Modality } & \multirow{3}{*}{$\begin{array}{l}\text { Size of the } \\
\text { company }\end{array}$} & \multicolumn{4}{|c|}{$\begin{array}{l}\text { Percentage of support for eligible project expenditure in fiscal } \\
\text { year } 2013\end{array}$} \\
\hline & & Individual project & \multicolumn{2}{|c|}{$\begin{array}{l}\text { Project in connection with } \\
\text { HEI/RC }\end{array}$} & \multirow{2}{*}{$\begin{array}{c}\text { Maxium support } \\
\text { limit per company }\end{array}$} \\
\hline & & $\begin{array}{l}\text { \% Company } \\
\text { spending }\end{array}$ & $\begin{array}{l}\text { \% company } \\
\text { spending }\end{array}$ & $\begin{array}{l}\text { \%HEl/RC } \\
\text { spending }\end{array}$ & \\
\hline INNOVAPYME & MIPYMES & $25 \%$ & $40 \%$ & $80 \%$ & 21 million \\
\hline INNOVATEC & Big Companies & $22 \%$ & $30 \%$ & \multirow{2}{*}{$75 \%$} & \multirow{2}{*}{36 million } \\
\hline \multirow{2}{*}{ PROINNOVA } & MIPYMES & \multirow{2}{*}{ N/A } & $65 \%$ & & \\
\hline & Big Companies & & $40 \%$ & $80 \%$ & 27 million \\
\hline
\end{tabular}

Source: Own elaboration with PEI data.

\section{Literature Review and Methodology}

The innovation system approach is a recognition that innovation ceases to be an isolated fact to be a social construct with visible economic effects, where knowledge-creating institutions previously not recognized by the market, actually facilitate the transit of the innovations they produce towards the firms where they are applied (Nauwelaers, 1995). The constant interaction between supply and demand generates a process of feedback, since part of the supply is increasingly influenced by the demand for knowledge, to incorporate it in the different spheres of the economy, generating an interactive learning between the different actors involved in the production and exchange of knowledge. A network vision allows to know the ways, channels and means in which the different members of the system make exchanges in the regions, based on the social capital and the existing institutional capacities.

In recent years, the regions and companies have been reconceptualized, due to the fact that, due to globalization and the opening up of markets, the increase in competition has generated a restructuring in the roles played by each one. The debate focuses on the internal capacity of the company to adapt to the new changes, seeking to improve its ability to innovate in the production process, or its ability to access new markets and produce new, improved and redesigned goods (Maskell and Malmberg, 1999). The second focuses on the economic success of some regions and their increase in the specialization of international trade, so that rather than focusing on individual enterprises, it does so in productive systems in which companies operate with external links and relations (Lawson, 1999).

An innovative territory becomes a primary source of resources for the decisions and actions that makes possible, and is characterized by the presence of a specialized production system, where a good part of the companies make efforts of technological innovation. Learning territories reflect the potential capacity of local actors to creatively mobilize existing resources as a product of the accumulation of knowledge generated by private, 
public, educational and research institutions, to foster specialized business and regional partnerships (Rozga, 2006).

Different works have contributed to the understanding of the effect of R \& D expenditure on the United States economy (Grilinches, 1979), the importance of the geographical proximity of the actors in the capture of the use of technological externalities that arise mainly from universities (Jaffe, 1989, Anselin et al., 1997). In Spain, Baumert and Heijs (2002) show that the innovations of the Spanish regions are positively dependent on the innovative effort made on the technological size of the enterprise, the degree of innovative culture and the existing cooperation. Alberdi, Gibaja and Parrilli (2014) in estimating the connectivity of Spanish RISs, identify that asymmetric behaviors that generate different system failures and justify the design of exclusive measures for correction in each observed region.

In Mexico, evaluating the fiscal stimulus program through a sample of firms Santos (2006) finds that firms presented additionality by developing important organizational capacities, but also generated learning to select their projects and organize them better to reduce times and costs. Ruiz (2008) discovers that the entities with the greatest capacity for innovation have been those where economies of agglomeration are observed and where the state has contributed to the formation of innovative inputs. Casas and Luna (2001) review the processes of building networks of knowledge potentially favorable to innovation at the regional level, based on public strategies and collaborative actions of HEIs, concluding that although the spaces of innovation are built in the geographical proximity of the actors, they can reach regional, national and even international dimensions, depending on their level of connectivity.

The concept of additionality justifies the intervention of the state to provide the necessary amount of investment that stimulates innovation projects, in the case of market failures that inhibit investment by imperfections in the capital market. The interaction and articulation of agents within an RIS, recognizes market failures as obstacles inherent in the innovation process itself (Heijs, 2012). However, government leverage can go beyond compensating for the low level of private sector R \& D investment, looking for changes in the behavior of agents to interact more and better (Larosse, 2001).

The effect of the PEI within, the companies with the methodology of the additional behavior is reviewed in a first moment, and then the analysis of social networks is applied to specify the level of interaction between the companies and the HEI and CI in the regional space (Lundvall, 2005).

A database of the period between 2009 and 2013 was constructed with the PEI minutes of the State Evaluation Subcommittee (ESS) of the Baja California, Mexico, considering the projects approved in each of the calls, which gives a total of 157 Projects. The ESS reviews 
whether the projects submitted are relevant and meet the criteria of quality, implementation and impact, to be evaluated by three experts selected from the Register of Accredited Evaluators.

To identify levels of additionality, information was obtained from a sample of 63 beneficiaries, designed with a confidence level of $95 \%$, to which an electronic survey was applied for each project. Although the counterfactual analysis allow us to examine whether the reaction of the firms is related to the PEI public policy or other unobserved factors, the network analysis was choose to identify levels of connectivity and centrality in the relationships, interactions, choices and structures built by the individuals and organizations to which they belong, making social capital prevail over human or individual capital (Wasserman and Faust, 1994). To do this an adjacency matrix was constructed to identify the relations between the actors, which was processed in the program UCINET 6 through the graphical construction of the network.

\section{Results}

The indicators of additionality

Investment: $61 \%$ of the projects had been operated with or without government support, wich indicates that public policy contributes $39 \%$ to the implementation of innovation and development projects, that are mainly related to the strategy of long-term innovation.

Vinculation: The 157 projects added 189 links, which allowed representatives of 72 percent of the projects to improve their perception of linkage. This has led them to establish lasting relationships; facilitating the exchange of knowledge; generate more innovative and higher quality products; and rethinking processes that help a more efficient production.

Participation of Researchers and Students: $72 \%$ of the projects had the support of some researcher and the rest were carried out with the own staff of the company. The main outcomes were three researchers per project, with variations from one to 12 and with a total of 111 researchers participating to carry out studies, specific analyzes or the use of laboratories. 58 percent of the projects involved students: 18 graduated from bachelor's degree, 17 master degree, and 5 from Ph.D.

Competitiveness: $51 \%$ of the projects obtained at least one new product as a result of the research, with a range between one and 23; and the spillover effect within the company by new ideas for improvement in other products, generates a synergy that usually has major effects. A new process within the company can have at least two effects: raising the level of productivity, modifying and improving the way things were done, or generating a level of saving man hours or less use of some input. 
The indicators of the network

The system consists of 62 companies, 18 universities and 6 research centers (14 local and 10 foreign), for a total of 82 actors. The group of companies consists of three categories: 35 micro and small, 15 medium and 12 large.

The total number of connections that the PEI could generate in the period 2009-2013 are 7,656. Of these, $65 \%$ are between companies, $10 \%$ between HEIs and $25 \%$ between companies and HEIs. Given the operating rules of the PEI, which does not encourage connections between companies, the total number of possible connections is reduced to 2,679 , and consequently generated a connectivity index of the Baja California RIS of $15 \%$, with 382 connections of the participating actors in the PEI. Within the reasons that a company has for choosing a link with an educational institution, are the trust, reputation, specialization and speed to formalize the link.

The actor with the most connections in the network is the state public university UABC, with 80 connections, which places it at the center of the innovation system. It highlights the case of Honeywell with 14 and Syworks with 13 connections. More connections mean more confidence and generate more possibilities of future relationships with new actors within the network.

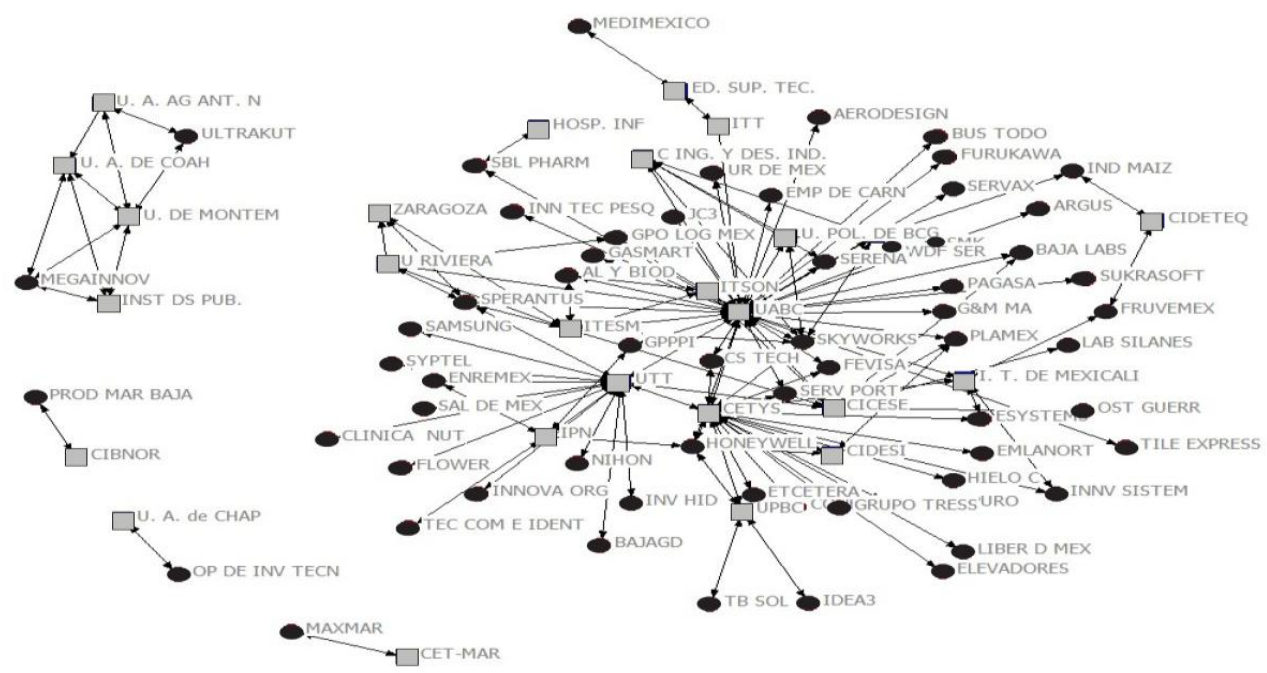

Figure 1.- Analysis of RIS Connectivity

Source: Own elaboration with PEI data.

The UABC has a high degree of intermediation, with $36 \%$, placing it in a position of actor bridge, with more control of information, communication and relationships between actors. With a correct strategy, this can grow in the short term. For a country like Mexico, it is very significant that a state public university (UABC) has the highest degree of intermediation 
within an RIS. In the absence of connection between companies, it can be the strategic bridge of processes of connection between them, since it is the largest space where the demand for innovation of companies is concentrated.

Table 2: Nodes intermediation in the Network

\begin{tabular}{|c|c|c|c|}
\hline INSTITUTION & $\begin{array}{c}\text { NUMBER OF NODE PAIRS ABLE TO } \\
\text { CONNECT }\end{array}$ & $\begin{array}{c}\text { OF INTERMEDIATE } \\
\text { DEGREE }\end{array}$ & $\begin{array}{c}\text { KIND OF } \\
\text { INSTITUTIONS* }\end{array}$ \\
\hline UABC & 3,467 & $36 \%$ & PUHEI \\
\hline CETYS & 1,787 & $19 \%$ & PRHEI \\
\hline UTT & 1,607 & $17 \%$ & PUHEI \\
\hline SKYWORKS & 437 & $5 \%$ & COMPANY \\
\hline HONEYWELL & 349 & $4 \%$ & PURC \\
\hline CICESE & 331 & $3 \%$ & PUHEI \\
\hline UPBC & 288 & $3 \%$ & PUHEI \\
\hline I.T. DE MEXICALI & 252 & $3 \%$ & PRHEI \\
\hline UAG & 200 & $2 \%$ & PUHEI \\
\hline IPN & 180 & $2 \%$ & PRHEI \\
\hline ITESM & 158 & $2 \%$ & THE REST \\
\hline REST INST. & 146 & $4 \%$ & \\
\hline
\end{tabular}

Source: Own elaboration with PEI data.

Note: PUHEIS, Public Higher Education Insitutions; PRHEI, Private Higher Education; PURC Public Research Center

\section{Concluding remarks}

Although a good percentage of the projects had been carried out even without government support, compared to the results of Mungaray, López and Moctezuma (2013), there is an improvement in the results of the program, since the percentage of projects canceled from failure to receive government support, rose from 18 percent to 39 percent. Similarly, the subsidy received by the companies, changed the perception of the linkage and the diversification of the links, motivating the projects to invest more and be more productive. The annual evaluation process guides companies to achieve better results, either through modification of their projects or suggestions for improvement, or through monitoring and evaluation of results as a whole. Although social arbitration is a practical way for knowledge to become a support to the competitiveness of companies, its acceptance by the business sectors accustomed to not arbitrate its decisions, has been slow but possible, thanks to the link with academic sectors, whose projects and products are always refereed.

From a construction perspective of RIS in Baja California, PEI contributes to companies maintaining their long-term technological trajectories, as it is well known that they are the first projects to be sacrificed in the face of investment or market uncertainty, are the long time projects, while the short term will projects continue even without government support. A second immediate impact is seen in the improvement of the capacities of human capital 
thanks to the expansion of cooperation networks with other companies and with HEI and CI, which undoubtedly generates long-term synergies. When a company is selected as part of a government support program to develop $\mathrm{R} \& \mathrm{D}$, has positive impacts on its image, increases its reliability and sends signals of solidity and innovative activity.

The PEI provides the same opportunity for access to the network, both for large and small companies, matching opportunities and benefits of belonging to them. The structure of the network is open, since new relationships can be created in each call, although the relationships can be repeated if a new collaboration is presented. In fact, this policy is solving a coordination problem inherent in an RIS, as the network encourages both the demand side of companies and the supply side to HEIs, inhibiting in both the natural aversion to cost and risk of generating new partnerships.

\section{References}

Alberdi, X., Gibaja J. \& Parrilli Mario (2014). "Evaluación de la fragmentación en los Sistemas Regionales de Innovación: Una tipología para el caso de España". Investigaciones Regionales. no. 28, España. pp. 7-35.

Anselin, L., Varga, A. \& Zoltan, Acs (1997) "Local Geographic Spillovers between University Research and High Technology Innovations", journal of urban economics, Vol. 42 issue. 3, US, November, pp. 422-448.

Baumert, T. \& Heijs, J. (2002). "Los Determinantes de la Capacidad Innovadora Regional: Una Aproximación Econométrica al Caso Español”. Madrid, UCM. Instituto de Análisis Industrial y Financiero no. 33. Documento de trabajo. pp.73.

Casas, R. \& Luna, M. Coord. (2001). La Formación de Redes de Conocimiento. Una Perspectiva Regional desde México. México, Ed. Anthropos. pp. 380.

Calderón, A. (2009). "INNOVATEC, INNOVAPYME, PROINNOVA. Evaluación externa en materia de diseño". Estudio realizado para Conacyt. pp.75.

CONEVAL (2013). Informe de Evaluación Específica de Desempeño 2012-2013. Innovación Tecnológica para Negocios de Alto Valor Agregado, Tecnologías precursoras y Competitividad de las Empresas. CONACYT, México. pp. 9.

FCCYT (2006). Diagnóstico de la Política Científica, Tecnológica y de Fomento a la Innovación en México (2000-2006). Foro Consultivo Científico y Tecnológico. A.C. México. D.F. pp.285.

Grilinches, Z. (1979)." Issues in Assessing the Contribution of Research and Development to Productivity Growth". Bell Journal of Economics, Vol. 10 No.1, UK, Spring, pp 92116.

Heijs, J. (2012). "Fallos Sistémicos y de Mercado en el Sistema Español de Innovación”. Innovación y Competitividad. no. 869. España, Noviembre-Diciembre, pp. 43-64.

Jaffe, A. (1989). "Real Effects of academic research". The American Ecomic Review. Vol. 79 No. 5, US, American Economic Association, Dec, pag. 957-970. 
Larosse, J. (2011). "Conceptual and Empirical Challenges of Evaluating the Effectiveness of Innovation Policies with Behavioural Additionality (the Case of IWT R\&D Subsidies)"IWT, Flanders. Working Paper. pp.14.

Lawson, C. (1999). "Toward Competence Theory of the Region". Cambirdge Journal of Economics. Vol. 23, UK, Cambridge University Press, pp.151-166.

Lundvall, B. (2005). "National Innovation Systems - Analytical Concept and Development Tool. Dynamics of Industry and Innovattion: Organizations, Networks and Systems". Conference document. Copenhagen, Denmark: Aalborg University, pp. 43.

Maskell, P. \& Malmberg, A. (1999). "Localised Learning and Insdustrial Competitiviness". Cambridge Journal of Economics. Vol. 23, UK, Cambridge University Press, pp.167-185.

Mungaray, A., López, S. \& Moctezuma, P. (2013). La Adicionalidad de los Fondos Públicos en la Innovación Empresarial Mexicana. En Caso de Baja California, 20012010. Revista de Educación Superior. Vol. (3). No. 167. pp. 41-62.

Nauwelaers, C. (1995) "Methodologies for the Evaluation of Regional Innovation Potential". Scientometrics. Vol. 34 No. 3, Netherlands, Akademiai Kiado, pp.497-511.

OCDE (2008). OCDE Reviews of Innovation Policy. Overall Assessment and Recommendations. Paris, OCDE, pp. 57

OCDE (2010). Perspectivas OCDE: México Políticas Clave para un Desarrollo Sostenible. Octubre de 2010. México, OCDE pp 40.

Rozga, R. (2006). "La importancia dimensión local y regional de los procesos de innovación tecnológica”. Aportes. Vol. V. VII, Número 20, México, UBP, pp 67-87.

Ruiz, C. (2008). "México: Geografía Económica de la Innovación". Revista de Comercio Exterior. Vol. 58 No.11.México, Bancomext, pp. 756- 768.

Santos, E. (2006). Adicionalidad de Comportamiento asociada a los Estímulos Fiscales en México: 2001-2005. Universidad Autónoma Metropolitana. México, Tesis de Maestría.

Wasserman, S. \& Faust, K. (1994). Social Network Analisis. Methods and Applications.. New York, USA, Cambridge University Press, pp 825. 